\title{
Perspectives From the Past for the Federal Reserve's Monetary Policy and Communication
}

\author{
Arto Kovanen ${ }^{1}$ \\ ${ }^{1}$ Kovanen Macroeconomic Policy Advising, L.L.C. , Alexandria, U.S.A. \\ Correspondence: Arto Kovanen, Principal, Kovanen Macroeconomic Policy Advising, L.L.C., Alexandria, VA \\ 22314, U.S.A. E-mail: arto.t.kovanen@gmail.com
}

Received: December 24, 2018

Accepted: January 5, 2019

Online Published: January 8, 2019

doi:10.5430/ijfr.v10n1p31

URL: https://doi.org/10.5430/ijfr.v10n1p31

\begin{abstract}
In this paper we analyze the Federal Reserve's policy and communication patterns during earlier tightening cycles to gain perspectives into the Federal Reserve's post-financial crisis monetary policy decisions and communication practices. While each interest rate cycle is unique, as is evident in the post-financial crisis normalization episode, there are regularities that could help inform us about future policy directions. In the post-financial period, the Federal Reserve has placed a great deal of emphasis on policy communication, in particular on its forward guidance, to minimize ambiguity about the future direction of monetary policy. We examine forward guidance during the earlier interest rate cycles and identify some common elements in the Federal Reserve's communication practices, which would be useful in interpreting the Federal Reserve's policy actions. This leads us to conclude that it would not be uncharacteristic for the Federal Reserve to suspend its campaign of raising interest rate at this stage of the normalization process, even if inflation risk remains. This underscored the importance of judgment in policy decisions, in part due to uncertainty about the neutral rate of interest, which is a benchmark that the Federal Reserve frequently refers to. In addition, historical trends in economic variables reveal patterns that could assist in evaluating the Federal Reserve's current and future policy decisions.
\end{abstract}

Keywords: monetary policy, policy communication, forward guidance

"The natural rate is an abstraction; like faith, it is seen by its works. ” [Orphanides and Williams (2002)]

\section{Introduction}

We examine the Federal Reserve's policy decision making and communication since the 1990s and draw parallels with past interest rate cycles to understand the Federal Reserve's policy actions. We illustrate how communication has been increasingly tailored to specific circumstances, particularly in the post-financial crisis era, to minimize uncertainties associated with the future direction of monetary policy. We attempt to read into the nuances of the Federal Reserve's communication (effectively, reading "between lines") to see how changes in the policymakers' language in the policy statements could be used to infer about the likely end to the campaign of hiking interest rates. Although this question is frequently discussed in the media these days, we go beyond current trends and adopt a broader perspective to the Federal Reserve's analysis and communication practices.

Reflecting its timeliness and possible nearing of the end to the policy normalization, the Federal Reserve has started discussing what should be the operational and communication practices during a period of more 'normal' monetary policy. The Federal Reserve has announced that it plans to review its practices during 2019, which the policymakers consider appropriate because the labor markets are close to full employment whereas inflation is near the 2 percent objective (see Board of Governors of the Federal Reserve System, 2018a). In relation to this, the Federal Open Market Committee (FOMC) discussed potential benefits and drawbacks associated with alternative frameworks for monetary policy implementation in November 2018 (Board of Governors of the Federal Reserve System, Minutes of the FOMC, 2018b). It explored both a regime where the supply of bank reserves was limited (effectively the operating model used prior to the financial crisis) and a regime where the supply of bank reserves was abundant, which has been in effect since the onset of the financial crisis. Albeit the views of the participants were highly tentative, the latter regime was thought to provide better control over the short-term interest rates in a variety of market conditions and effectively transmit interest rates signals to the broader financial markets (Note 1). 
The main contribution of this paper is to highlight parallels between past and current tightening cycles, to help us better understand current and future policy actions. In particular, we examine policy communication related to forward guidance and how it has changed in response to economic circumstances during the past interest rate cycles. We recognize that each interest rate cycle has its unique determinants and a great deal of judgment goes into each policy decision, which is complemented by data available to the policymakers. Nevertheless, we expect to find common elements in each interest rate cycle. We also discuss typical risk factors frequently brought up in the Federal Reserve's policy discussions, such as tight labor markets and its implications for wage-price dynamics, the strong appreciation of the U.S. dollar, and the inverted yield curve. Similarities with past trends reveal that such analysis could be helpful in understanding current and future policy decisions. We also discuss challenges facing the Federal Reserve in using the neutral (natural) rate of interest for monetary policy assessment.

The paper is organized as follows. Section 2 discusses some of the key uncertainties frequently highlighted in the Federal Reserve's policy discussions, such as the tight labor markets and wage-price dynamics, the dollar appreciation, and the risks arising from an inverted yield curve. This discussion draws parallels with previous interest rate cycles and illustrates that current developments are hardly unique, underscoring that economic events are never truly random. Section 3 introduces a framework for monetary policy analysis and communication, which outlines the basic elements for how to analyze monetary policy and decision-making. It also highlights the importance of communication on monetary policy. In Section 4 we consider challenges facing the policymakers in using an uncertain neutral (natural) rate of interest as a benchmark for monetary policy assessment. Section 5 chronicles the evolution of the Federal Reserve's communication practices after the financial crisis, paying particular attention to the evolution of forward guidance. This discussion documents modifications in the communication practices and how intimately they are linked to the policymakers' macroeconomic analysis. Section 6 offers perspectives to the current policy discussion from past interest rate episodes and highlights linkages between economic developments, policy decisions, and communication. This illustrates how current policy developments have parallels in the past, which helps in understanding current policy developments and place them in the longer-term content. In Section 7 we conclude and offer thoughts on the future direction of U.S. monetary policy.

\section{Economic Uncertainties and Their Implications for Monetary Policy}

The Federal Reserve adjusts its short-term policy interest rate (in the United States, the federal funds rate target range) in response to economic developments and changes in its outlook to achieve its stated policy mandate of maximum employment and price stability. The desire to accomplish that is made clear in the published minutes of the FOMC. This, however, involves dealing with risks and uncertainties inherent in the determination of monetary policy. Following is a quotation from the September 2018 FOMC minutes that highlights some of the risks and uncertainties currently in the minds of the policymakers:

"Participants generally agreed that risks to the outlook appeared roughly balanced. Some participants commented that trade policy developments remained a source of uncertainty for the outlook for domestic growth and inflation. The divergence between domestic and foreign economic growth prospects and monetary policies was cited as presenting a downside risk because of the potential for further strengthening of the U.S. dollar; some participants noted that financial stresses in a few emerging market economies (EMEs) could pose additional risks if they were to spread more broadly through the global economy and financial markets. With regard to upside risks, participants variously noted that high consumer confidence, accommodative financial conditions, or greater-than-expected effects of fiscal stimulus could lead to stronger-than-expected economic outcomes. Tightening resource utilization and an increasing ability of firms to raise output prices were cited as factors that could lead to higher-than-expected inflation, while lower-than-expected growth, a strengthening of the U.S. dollar, or inflation expectations persistently running below 2 percent were mentioned as risks that could lead to lower inflation.

A few participants offered perspectives on the term structure of interest rates and what a potential inversion of the yield curve might signal about economic prospects in light of the historical regularity that an inverted yield curve has often preceded the onset of recessions in the United States. On the one hand, an inverted yield curve could indicate an increased risk of recession; on the other hand, the low level of term premiums in recent years--reflecting, in part, central bank asset purchases--could temper the reliability of the slope of the yield curve as an indicator of future economic activity. In addition, the recent rise and possible further increases in longer-term interest rates might diminish the likelihood that the yield curve would invert in the near term." [The Board of Governors of the Federal Reserve System, Minutes of the Federal Open Market Committee, 2018c, pages 7-8]

The policymakers invariably face uncertainties when implementing monetary policy, as there is no risk free path to policy formulation. Alan Greenspan, former Chairman of the Federal Reserve, illustrated this point in his thoughts 
about the uncertainties associated with the ongoing expansion in the U.S. some 20 years ago, which is relevant in today's moment. He noted that while there were few signs of imbalances and inflationary tensions at the time, and the cyclical upswing was approaching six years in duration, the U.S. economy continued to retain considerable vigor (Note 2). While the U.S. economy faced some two decades ago a situation where the late economic cycle was not fully compliant with standard economic modeling, creating uncertainties about the future direction of monetary policy, Chairman Greenspan was aware that economic events are never truly random and could be predicted at least with some degree of certainty. As Greenspan stated it, there are certain empirical regularities in behavioral relations that could be followed with some degree of confidence, although each business cycle has its unique features. This highlights the value of developments in the past. In order to gain perspective and identify patterns in the current trends, we compare them with past developments since the early 1980s (Note 3).

\subsection{Labor Markets and Wage-Price Dynamics}

Developments in the U.S. labor markets have been at the center in recent policy discussions. After the post-financial crisis the sharp drop in labor utilization was followed by a painfully slow recovery, as the rate of unemployment returned to a more normal level only gradually. This prompted the Federal Reserve to keep interest rates close to zero for an extended period of time and focus its forward guidance on regaining maximum employment, for instance by establishing an explicit threshold for the rate of unemployment, as inflation was not the primary concern. More recently, as the economy has recovered, the tight resource use and increasing ability by corporations to raise prices have led to concerns that these developments could result in higher inflation, as noted for instance in the September 2018 FOMC minutes.

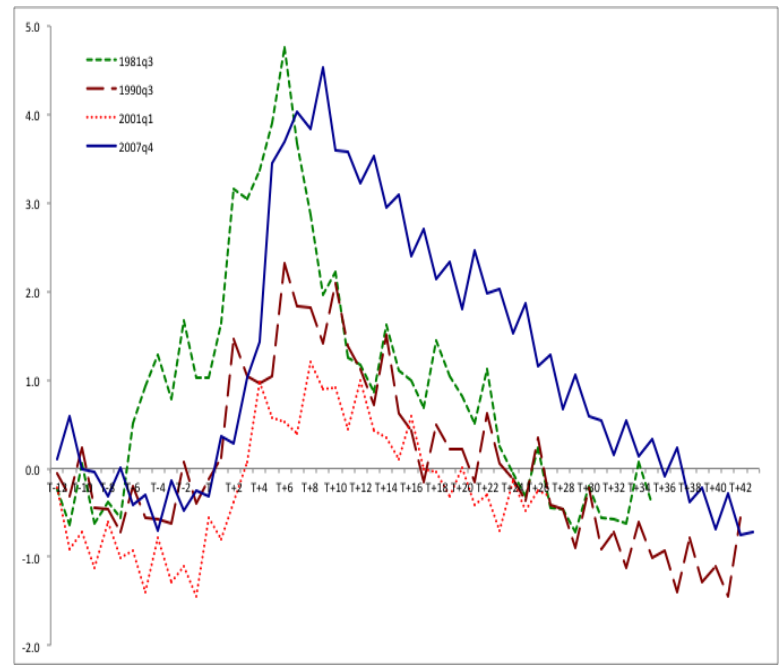

Figure 1. Unemployment rate gap, rebased (U-3 measure, actual minus natural rate)

Sources: Federal Reserve Bank of St. Louis and the author.

Figure 1 shows that closing of the unemployment gap has been slow in the current recovery, much more so than during previous recoveries (Note 4). It took a total of 36 quarters to return unemployment rate to full employment level (estimated by the natural rate of unemployment). While the 1981 recession illustrates a similar rise in the rate of unemployment, the unemployment gap vis-à-vis natural rate was closed much faster (in 24 quarters) during that recovery. The recessions of 1990 and 2001 were somewhat less severe, at least in terms of their impact on the unemployment rate gap, and consequently progress towards full employment was made sooner. Reich (2010), for instance, suggests that the sharp rise in long-term unemployment following the financial crisis was a factor behind the slow reduction in the overall unemployment rate.

Whether the tight labor market gives way to accelerating wages and prices in not evident. Price developments are often influenced by a multitude of factors other than wages and salaries (although labor costs are probably most important). Low unemployment has failed to result in a rapid growth in labor costs during the current recovery, While wage growth has recovered, it only stood at 3.1 percent in November 2018 , which is modest by historical 
standards. Inflationary pressures also remain contained. See Daly and Hobijn (2016).

Historically, nominal wage growth at current stage of economic recovery should be much faster. During past 3 recoveries nominal earnings grew more than 4 percent. Kovanen (2017a), for instance, links modest wage growth to capacity utilization, which in the current recovery has been low. It may have allowed firms to substitute labor for other inputs and thus reduce pressures on wages, albeit not evenly across industries (Note 5). Large firms have more options to organize production than smaller enterprises (in the latter group labor is often the primary input). Ability to do so varies by industry. For instance, in the service sector where labor intensity is high flexibility is likely to be limited. Other studies point to competitive pressures and flattening Phillips curve (for instance, Bean, 2006, and IMF, 2006) as factors explaining low inflation pressures (see also Powell, 2018a). Capacity utilization in manufacturing in the third quarter of 2018 was 76.4 percent, which is well below levels typically observed at the mature stage of economic recovery. For instance, Carner (1994) estimated that capacity utilization rate in the United States consistent with stable inflation was around 80 to 82 percent between the 1960s and until early 1990s, suggesting that further tightening in the capacity utilization might be needed before significant inflation pressures would emerge.

For comparison, in the late 1990s, a prolonged labor demand above full employment levels did not lead to inflationary pressures. During the latter part of the 1990s, unemployment rate was below the natural rate for 16 quarters (compared to 6 quarters during the ongoing recovery). The unemployment rate gap averaged -0.9 percent during the late 1990s, which is more that twice as wide as the current unemployment gap) (Note 6). This illustrated the challenges policymakers face in correctly estimating the slack in the economy and how it might impact wages and inflation. Current estimates of the natural unemployment rate could easily overstate the actual level of unemployment consistent with price stability (i.e., $\mathrm{u}^{*}$ ), which could lead to policy errors (Note 7).

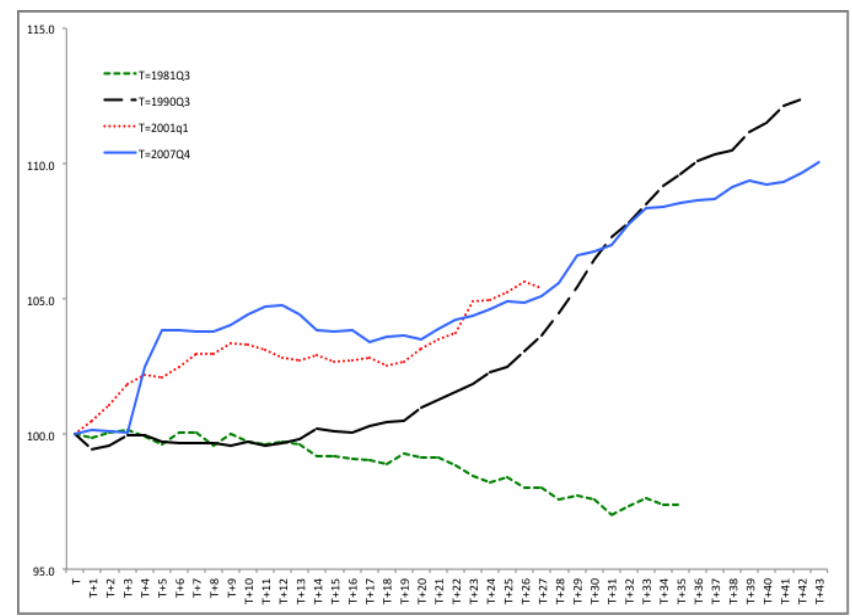

Figure 2. Average hourly earnings PCE inflation-adjusted (Rebased; T=100)

Sources: Federal Reserve Bank of St. Louis and the author.

Nevertheless, moderate inflation has pushed labor compensations up (Figure 2). While nominal hourly earnings have grown only about $2 \frac{1}{3}$ percent annual rate since 2015 , which is not fast in the current environment, inflation also has been muted (averaging 11/4 percent per year in the same period). After adjusting for inflation, we notice that earnings increased sharply in the period immediately following the financial crisis, starting in the last quarter of 2008. This was caused both by the continued steady increase in nominal wages and the deflationary pressures during 2009 (the price level actually dropped, as measured by the Personal Consumption Expenditure (PCE) price index). The recovery following the 2001 recession shares a similar pattern (i.e., real earnings grew despite rising unemployment), albeit in somewhat different circumstances. In the current recovery, inflation-adjusted hourly earnings are some 10 percent above their pre-crisis levels, which is not insignificant. Figure 2 shows that current increases in the hourly earnings are only slightly below the levels of the 1990s economic recovery. 


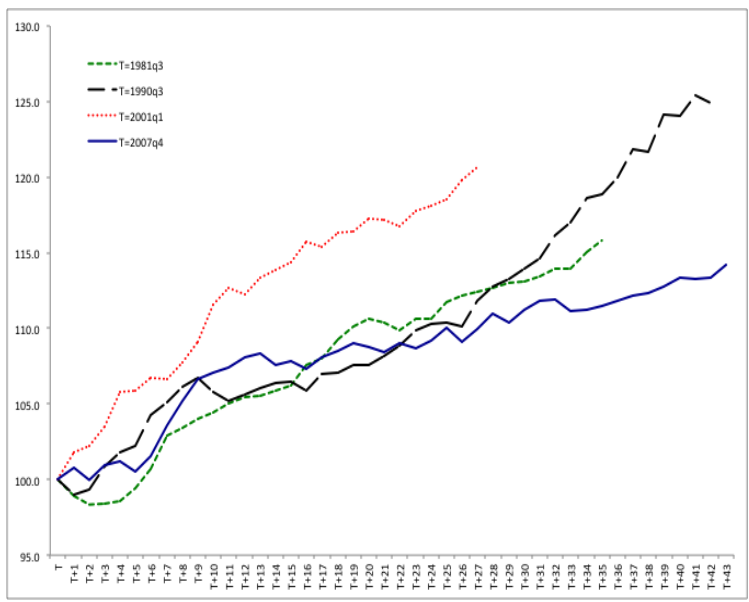

Figure 3. Output per hour worked (Rebased; $\mathrm{T}=100$ )

Sources: Federal Reserve Bank of St. Louis and the author.

Another source of uncertainty relates to the future productivity growth and if it is going to accelerate going forward. This will be critical for determining whether higher labor costs will lead to rising inflation pressures. Figure 3 shows labor productivity in the early stages of current recovery was not unusual, as often thought, but seems to have followed a path similar to earlier recoveries (with the exception of post-2001 recovery). During the first seven years following the recession, output per hour worked has increased roughly 10 percent during most recoveries since the 1980s. However, after that the trends deviate. The 1990 recovery stands out and shows a sharp acceleration in labor productivity during the second half of the 1990s, which permitted the Federal Reserve to maintain monetary policy accommodation longer without the risk of rising inflation. In addition, it is not apparent to what extent the increase in labor productivity in the current recovery is either cyclical or permanent, which has important policy implications (this has been noted by Clarida, 2018a). Should productivity growth accelerate on a permanent basis, as it did during the 1990 s, it has the potential to allow the U.S. economy continue expanding without rising inflation pressures. See also Cette et al. (2016) who study the causes and implications of slow productivity growth during the financial crisis.

\subsection{Dollar Appreciation and Headwinds for the U.S. Economy}

Participants of the FOMC have frequently repeated their concerns about the strong U.S. dollar. Recent trade policy uncertainties and weaker economic developments abroad have compounded this and pose additional downside risk for economic expansion and inflation going forward (Board of Governors of the Federal Reserve System, Minutes of the FOMC, 2018d). Figure 4 shows that the U.S. dollar has strengthened by some 30 percent against major currencies in inflation-adjusted terms, most of it since 2015. This is large by historical standards but similar in magnitude to the increase in the inflation-adjusted U.S. dollar in the aftermath of 1990 recession (Note 8).

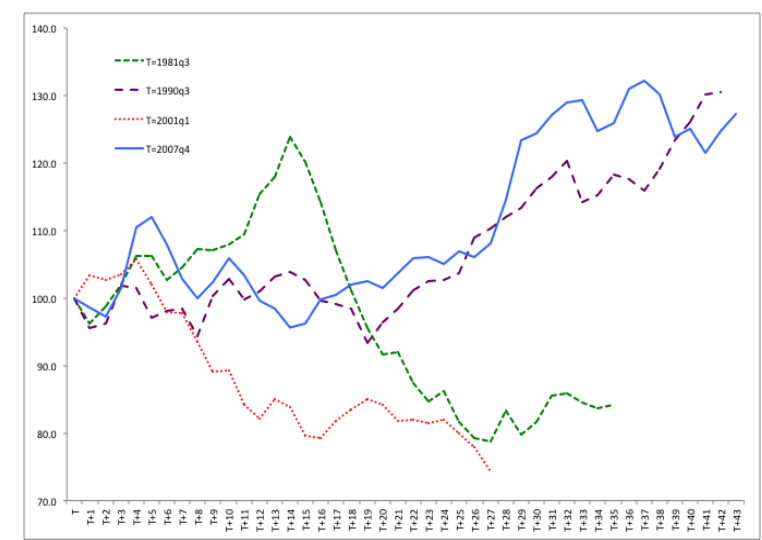

Figure 4. U.S. dollar against major currencies (Inflation-adjusted, rebased; T=100)

Sources: Federal Reserve Bank of St. Louis and the author. 
The continued dollar strength could pose a dilemma for the policymakers. It is likely to impact real output, mainly through its effect on trade. This was apparent in the late 1990s when strong U.S. dollar was associated with the widening of trade imbalance and slowing growth. Díez and Gopinath (2015) estimate that the strong U.S. dollar has widened U.S. trade by reducing exports more than increasing imports. This is because export prices tend to adjust downward by almost the full amount of the currency appreciation while the impact on imported goods prices is more limited. On the other hand, downward pressure on consumer prices is weaker, as one percent rise in the dollar only reduces inflation by 0.15 percent in the short run and 0.25 percent in the long run. A strong dollar would reduce manufacturing investments and profitability, which would affect output negatively (Blecker, 2007).

\subsection{Yield Spread as a Predictor of Recession}

An inverted yield curve is often thought to indicate an increased risk of recession. This regularity was noted in the September 2018 FOMC minutes. When yield curve becomes inverted (short-term interest rates are higher (e.g., due to Federal Reserve's monetary policy tightening) than longer-term interest rates (reflecting longer-term expectations), in the past this has been a good predictor of forthcoming recession. Figure 5 illustrates the dynamics of the yield curve spread (the difference between the yields of ten-year and two-year constant maturity securities of the U.S. Treasury, which is one measure that is frequently used in this context). During previous downturns, the yield curve spread has turned negative ahead of each recession, albeit the length of time when this happens and the size of the negative yield spread have fluctuated. Furthermore, excluding the 1981 recession, the yield curve has turned positive every time before the start of a recession.

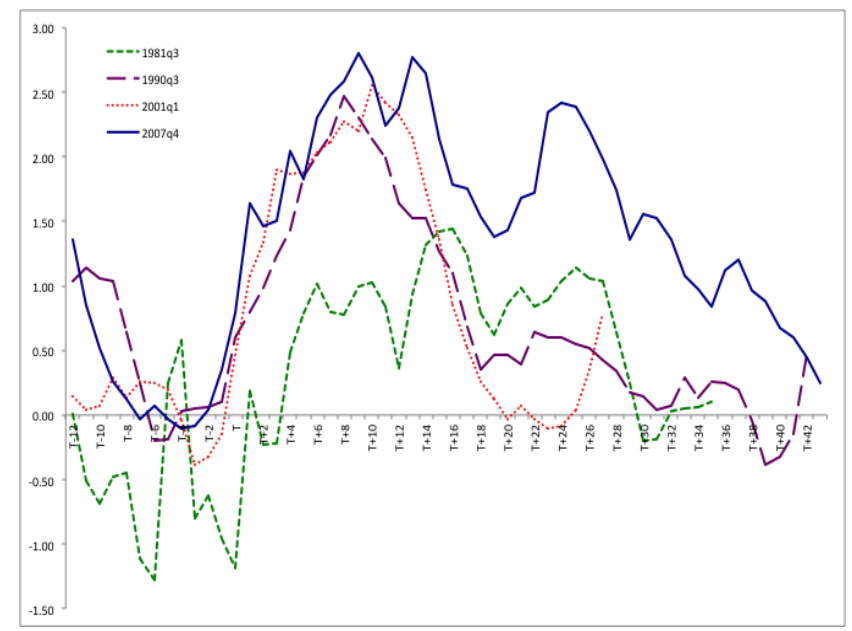

Figure 5. Ten-to-two year yield spread, rebased (In annual percent)

Sources: Federal Reserve Bank of St. Louis and the author.

It is somewhat unexpected that despite differences in the paths of short-term interest rates, the yield curve spreads are highly similar across various recessions. At its peak (i.e., when the yield curve is the steepest), the yield curve spread has typically widened to about 250 to 300 basis points in all cases except the 1981 recession. However, there are notable differences in these paths when the yield curve spread narrows in the course of the recovery, which is influenced, among others, by the path of monetary policy in the recovery. During the recovery from the financial crisis, the yield curve spread has remained wider for longer than in the past, reflecting the more gradual 'normalization' of monetary policy in the aftermath of the crisis.

Despite its regularity, the flattening of the yield curve, or inversion, may not necessarily signal recession in the immediate future due to distortions. Members of the FOMC have pointed to the low term premiums in recent years, in part reflecting the Federal Reserve's asset purchases, which could distort the reliability of the slope of the yield curve as an indicator of future economic activity. The Federal Reserve Bank of New York calculates that the probability of a recession using the yield curve spread (calculated as the difference between the 10 year and 3-month Treasury yields) was only 15 percent in November 2018. While the yield curve spread may have since narrowed further, suggesting that the probability of a recession has risen using this analysis, the probability is still substantially 
below levels observed in the past pre-recession periods. This indicates that the current economic recovery may still have some length to go even if the yield curve spread turns negative in the near future.

Nevertheless, the policymakers need to pay attention to the flattening yield curve (see, for instance, Estrella and Trubin, 2006) and Estrella and Mishkin, 1996). During the previous interest rate cycles, the length of time between inversion of the yield curve and a recession has been approximately four to five quarters. Christensen (2018), echoing the concerns of the policymakers, points out that the protracted decline in the natural rate of interest and massive asset purchase operations of the Federal Reserve and other global central banks, have contributed to the historically low longer-term yields that might be less responsive to increases in short-term interest rates than in the past. As a result, the signal imbedded in the yield curve spread may be less reliable than in the past. Bonis et al. (2017) estimate that distortion in the term premium due to Federal Reserve's quantitative easing was about 85 basis points at the end of 2017, which is substantial. As the holdings of securities in the SOMA account are reduced to more normal levels, this will put upward pressure on longer-term interest rates and consequently reduce the distortion in the term premium (Note 9). See also Bauer and Mertens (2018).

\section{How to Think About 'Normal' Monetary Policy?}

What does a 'normal' monetary policy look like? John Williams, current President of the Federal Reserve Bank of New York, asked this very question in his recent speech at Columbia University (Williams, 2018). It is a highly relevant question in the current environment, because a protracted period of time has passed since the Federal Reserve's monetary policy was considered as 'normal', and because many believe that the Federal Reserve is nearing a 'normal' monetary policy stance (see also Powell, 2018a and b).

In his address, Williams discusses the evolution of the Federal Reserve's monetary policy since the start of the financial crisis. Williams distinguishes between three stages in this process. The first stage, called the lift-off, occurred in December 2015 when the FOMC began for the first time following the financial crisis to raise the target range for the federal funds rate that had been kept near zero for 7 years (since December 2008). The second stage in the normalization process comprises two elements, according to Williams: a gradual increase in the federal funds rate target closer to a 'normal' level (although he is not very specific what a 'normal' level would mean; we will return to this question later in the paper), while reducing the size of the Federal Reserve's balance sheet (i.e., divesting its holdings of Treasury and agency securities), which expanded five-fold during the post-financial crisis period as the Federal Reserve acquired securities through its quantitative easing operations (Note 10). The third and final stage is called a 'normal' monetary policy stance. Williams argues that a key feature of a 'normal' monetary policy stance is that the direction of future monetary policy will no longer be clear-cut, although the path for the federal funds rate will continue to be guided by the Federal Reserve's dual mandate of maximum employment and price stability. That is, the Federal Reserve could tighten or ease monetary policy in response to changes in the underlying circumstances and in its economic outlook.

We typically describe monetary policy in terms of the familiar Taylor rule (Taylor, 1993), which can be expressed with Equation (1) below:

$$
\mathrm{i}_{\mathrm{t}}=\pi_{\mathrm{t}}+\mathrm{r}_{\mathrm{t}}^{*}+0.5^{*}\left(\pi_{\mathrm{t}}-\pi_{\mathrm{t}}^{*}\right)+0.5^{*}\left(\mathrm{u}_{\mathrm{t}}-\mathrm{u}_{\mathrm{t}}^{*}\right)
$$

where $\mathrm{i}=$ the federal funds rate, $\pi=$ inflation rate, $\mathrm{r}^{*}=$ the natural rate of interest $\pi^{*}=$ Federal Reserve's inflation objective (currently 2 percent annual rate), $\mathrm{u}=$ unemployment rate, and $\mathrm{u}^{*}=$ the natural rate of unemployment (Note 11). According to the Taylor rule, monetary policy will be guided by 3 familiar components: the natural rate of interest, inflation gap and unemployment gap. Even though the Taylor rule is thought to provide a simplified illustration of the way U.S. monetary policy works, with a relatively good track record to support it, at least before the financial crisis, in practice, however, the Federal Reserve does not formulate monetary policy based on a fixed rule, but instead uses a broad set of economic data and indicators against which the monetary policy stance is evaluated. Taylor (1993) assumed in his paper that the natural rate of interest ( $\left.\mathrm{r}^{*}\right)$ was 2 percent and invariant over time, which subsequent research has shown to be inaccurate.

Equation (1) clearly illustrates the challenges policymakers face, as the natural rates of interest ( $r^{*}$ ) and unemployment $\left(\mathrm{u}^{*}\right)$ are not directly observable. Any misspecification in the natural rate of interest, for instance, has the potential to lead to the misspecification of the federal funds rate target relative to what it ought to be if the natural rate of interest was estimated accurately. This could risk the policymakers to tighten monetary policy too much, which could cause a recession. In the opposite situation, the Federal Reserve might allow monetary policy to remain too accommodative for too long, which could result in a runaway inflation (see Orphanides and Williams, 2002, for a useful discussion on this issue). Because of the inherent difficulty in accurately estimating the natural rates and the 
errors in these estimates, the policymakers are likely to prefer a gradual approach to monetary policy implementation, and tighten monetary policy while looking for signs of getting closer to a 'neutral' policy stance. Clarida (2018b) notes that inflation-adjusted federal funds rate is much closer to the vicinity of the natural rate compared to December 2015 when the FOMC began the removal of monetary accommodation; however, how close remains a matter of judgment.

Since monetary policy impacts the economy with variable lags, it is essential that the policymakers are forward looking. Consequently, the policymakers need to take actions before developments actually materialize (see, for instance, Alan Greenspan, 1996). This underscores the important role played by communication. Communication is typically conveyed to the public through the regular publication of FOMC's policy statements and published minutes of the policy meetings, as well as through speeches and other means. While communication has always been important for monetary policy implementation in the United States, unusual severity of the financial crisis and slow recovery that followed, combined with significant uncertainties associated with the path of economic recovery and its durability, placed a premium on clear communication. The policymakers have used forward guidance to help guide expectations of the public and reduce uncertainties about the Federal Reserve's future policy actions. Yellen (2013), for instance, underscores the importance of communication and forward guidance in monetary policy implementation. She also stresses that communication will play an important role in managing the transition to a 'normal' monetary policy stance.

At times of cyclical downturns, such as during the financial crisis and its aftermath, uncertainties that surround macroeconomic projections could become unusually large. For instance, Yellen (2017) discusses the challenges in accurately forecasting the future paths of employment and inflation. Although usually the situation, the FOMC has repeatedly highlighted during the post-financial crisis period that the timing of interest rate increases is not set on a pre-determined path but would depend on incoming economic data as well as on progress towards accomplishing the Federal Reserve's dual mandate of maximum employment and price stability. Policymakers have struggled, possibly more than customary, to find a balance between tightening monetary policy too soon and risking maintaining an accommodative policy stance for too long (e.g., see Board of Governors of the Federal Reserve System, Minutes of the FOMC, 2015a). Tightening too early, or too aggressively, risks weakening the economy and shortening the recovery, which could force the policymakers to reverse their policy course at a later stage. This could lead to a situation where the process of healing damage from the crisis is shortened (e.g., related to the balance sheets of financial institutions), which could raise the risk that severe cyclical effects become permanent. On the other hand, a protracted monetary accommodation could lead to an overheating of the economy and to acceleration in inflation pressures, and undermine financial stability. This may require the policymakers to raise interest rates faster during a subsequent period to regain control of inflation, which might contribute to an economic downturn.

\section{Monetary Policy Analysis and Neutral Rate of Interest}

The FOMC makes frequent references to the neutral (or natural) rate of interest in its policy statements. The natural rate of interest is understood to be an interest rate, after adjusted for inflation, that is consistent with unemployment rate at its natural level while inflation remaining stable (Orphanides and Williams, 2002). The natural rate of interest is intended to provide a benchmark for the future path of policy rates. In carrying out such a strategy, the policymakers are expected to have an accurate understanding of the level of the natural rate of interest at any point in time (the same applies to the natural rate of unemployment).

There are significant challenges in relying on the natural rate for policy assessment. As we quoted in the beginning of the paper, the natural rate of interest is "like faith, it is seen by its works" (Orphanides and Williams, 2002). This is because the natural rates of unemployment and interest cannot be observed directly and in the absence of precise estimates of these rates (Equation 1), there is no reliable anchor to evaluate monetary policy. When policymakers are unable to accurately estimate the errors associated with natural rates, Orphanides and Williams argue that a strategy that would not require any knowledge of the natural rate and consequently is not influenced by misperceptions in the natural rate of interest, would serve the policymakers better.

The natural rate of interest became highly negative in the aftermath of the financial crisis. Furthermore, it is believed to have returned to a positive level only recently (for instance, Barsky et al., 2014, and Laubach and Williams, 2003, who show that the natural rate is pro-cyclical and volatile). Holston et al. (2016) and Dorich et al. (2017) show that the natural rate of interest has demonstrated a secular decline and has fallen during past two decades, not just in the aftermath of the 2007 financial crisis. However, estimates of the natural rate are subject to a significant degree of uncertainty (Note 12). Lubic and Matthes (2015) also underscore the secular decline in the natural rate of interest.

Several factors may have distorted the information content of the natural rate of interest. Krustev (2018), for instance, 
notes that financial factors could have distorted the link between interest rates and the output gaps and led to bias estimates of the natural rate of interest. Headwind due to financial deleveraging have lowered the natural rate of interest, which might have adversely impacted the way interest rate cuts help stimulate the economy and push inflation back to the target level. Clarida (2018b) emphasizes that uncertainties associated with the estimates of the natural rates of interest and unemployment require that the policymakers update their estimates of these rates frequently with new incoming data. See Carlstrom and Fuerst (2016).

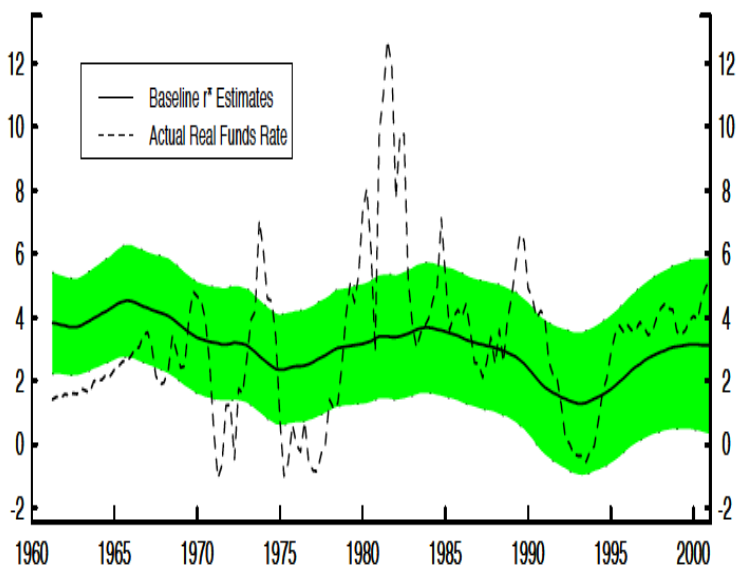

Figure 6. Estimates of the natural rate and inflation-adjusted federal funds rate (In annual percent)

Source: Laubach and Williams (2003).

Estimating the natural rate of interest accurately is therefore essential to minimize policy errors. Yellen (2016), for instance, argues that the policy interest rate at the end of the tightening cycle often exceeds the neutral interest rate (e.g., Figure 6). As a consequence, part of the past reduction in the policy interest rate during a downturn reflects the unwinding of earlier tightening of monetary policy above the neutral rate of interest. This is an important observation and suggests that the Federal Reserve might have missed its longer-term interest rate anchor during earlier tightening episodes. It underscores the practical difficulty in anchoring monetary policy to volatile estimates of the natural rate of interest. Koenig and Armen (2017), and Roberts (2018), suggest that the federal funds rate may still be below the estimated natural rate of interest, which implies that further tightening may be required to reach a 'normal' policy stance. Furthermore, Powell (2018b) recently noted that interest rates remain below the broad range of estimates of the level that would be neutral for the economy. Consistent with this, Liu (2018) shows that the neutral rate of interest is currently around 2.75 percent and remains 25 basis points above the upper end of the target range for the federal funds rate in December 2018. This suggests that the Federal Reserve is likely to increase the target range for the federal funds rate at least one more time.

Policymakers have raised concerns that the low level of the natural interest rate could complicate monetary policy implementation in the future. That is, stabilizing inflation around the policymakers' 2 percent goal in the current environment could take place at a level of the federal funds rate that is lower than in the past (Yellen, 2016) (Note 13). Which leads Yellen to worry that this could constrain the Federal Reserve's ability to reduce interest rates in future downturns before reaching the zero lower bound (based on this some have suggested that it would justify raising interest rates further to create space for future policy easing). Reifschneider (2016), however, argues that even if the federal funds rate in the future remains lower than in the past, the Federal Reserve would still be able to manage interest rates with its existing policy tools (i.e., its asset purchases and its forward guidance could be used to push longer-term interest rates lower and increase downward pressure on future short-term rates).

\section{Forward Guidance in the Aftermath of the Financial Crisis}

In this section we discuss how the Federal Reserve's forward guidance has evolved in the post-financial crisis period. While we chronicle the key changes in the Federal Reserve's forward guidance, we also link adjustments in the forward guidance to changes in the underlying developments in the economy and the policymakers' outlook, as the economic recovery progresses. This underscores the critical importance of monetary analysis as a foundation behind interest rate decisions and policy formulation in modern central banking (see, for instance, Bernanke, 2013). 
Following the financial crisis, the Federal Reserve has paid particular attention to forward guidance. This was seen as critical to reduce the uncertainty on future monetary policy and the likely path of the federal funds rate. It helped inform the financial markets about the possible timing of future policy actions and the exit from the unconventional monetary policy. Forward guidance has been modified several times during the post-financial crisis period, as the economic circumstances have changed. In the early phase of the economic recovery, forward guidance took the form of 'qualitative' language imbedded in the FOMC's press statements (for instance, Kovanen, 2014) (Note 14). Date-based guidance was introduced in August 2011 when the FOMC included a specific date into its guidance, stating that economic conditions would likely to warrant keeping the federal funds rate target near zero "at least through mid-2013" (Board of Governors of the Federal Reserve System, FOMC press statement, 2011a). This date-based guidance was extended twice during 2012, first until late 2014 and later until mid-2015 (see also Bernanke (2013) who argues that forward guidance helped clarify under what circumstances further changes might be introduced to the guidance).

Another form of forward guidance was introduced in January 2012, comprising the publication of FOMC members' assessments for the target path of the federal funds rate (Kovanen, 2014, and Bernanke, 2017a). Earlier the participants' quarterly projections of macroeconomic variables (i.e., inflation, output growth, and the unemployment rate) were included in the Federal Reserve's Summary of Economic Projections (SEP). Since January 2012, the FOMC has issued an annual statement in which it explains its longer-term goals and policy strategies (Board of Governors of the Federal Reserve System, 2018e, for the most recent version). As part of this statement, the FOMC for the first time established an explicit longer-term goal for inflation ( 2 percent), which has brought the Federal Reserve closer to becoming an inflation-targeting central bank (e.g., the International Monetary Fund does not classify the Federal Reserve's monetary policy framework as "inflation-targeting"; see Table 2 of IMF, 2018), while pointing to the SEP for information about the FOMC participants' assessment of the longer-term normal unemployment rate. These measures were part of the FOMC's effort to strengthen the Federal Reserve's monetary policy transparency and accountability. By making more information available to the public about its policy goals and strategies, as well as on its economic forecasts, the Federal Reserve aimed at providing a clear framework to help the public understand and anticipate its policy actions. Bernanke (2017a) argues that this has made monetary policy more efficient and strengthened the Federal Reserve's institutional credibility. The FOMC also started organizing post-meeting press conferences and publishes regularly information about its balance sheet and specific liquidity facilities, which were aimed at clarifying its thinking behind policy decisions.

Subsequently, the Federal Reserve linked its forward guidance more directly to its economic objectives. In December 2013, it introduced so-called state-contingent guidance by announcing for the first time that no increases in the federal funds rate target should be anticipated so long as the rate of unemployment remained above $61 / 2$ percent, provided that inflation remained stable and near its target level and inflation expectations were well anchored. In its communication the FOMC emphasized that this condition was to be understood as a threshold, not a trigger for an interest rate increase. It indicated that the target range for the federal funds rate would not be adjusted (i.e., raised) in an automatic manner when the threshold was reached. According to Bernanke (2013), this allowed the Federal Reserve to keep monetary policy 'on hold' even after unemployment had fallen below $61 / 2$ percent, and seek 'assurances' that the labor market was sufficiently strong before any increases in the target range for the federal funds rate would be considered. Bernanke (2013) has pointed out that the FOMC realized the drawbacks in using unemployment rate as the threshold for future monetary policy guidance, but considered unemployment rate as probably "the best single summary indicator of the state of the labor market" at the time. See also Bernanke (2012) and Campbell (2013).

As unemployment rate approached the 61/2 percent threshold, the FOMC modified its guidance in 2014. It highlighted the importance of a broad range of data in assessing economic conditions, while the FOMC indicated it would keep the current target range for the federal funds rate unchanged for a "considerable time" after it has completed its asset purchase program, provided that inflation continued to run below the FOMC's 2 percent objective and inflation expectations remained well anchored (e.g., Yellen 2014 and the Board of Governors of the Federal Reserve System, FOMC press statement, 2014a). The new language provided information about the likely path of the target range for the federal funds rate once the FOMC began removing policy accommodation. In particular, it stated that economic and financial conditions might warrant, for some time, to keep the target federal funds rate below levels that the FOMC viewed as 'normal' in the longer run (without specifying what 'normal' would mean), even after employment and inflation were near their mandate-consistent levels $\left(\pi^{*}\right.$ and $\mathrm{u}^{*}$ in Equation (1)). 


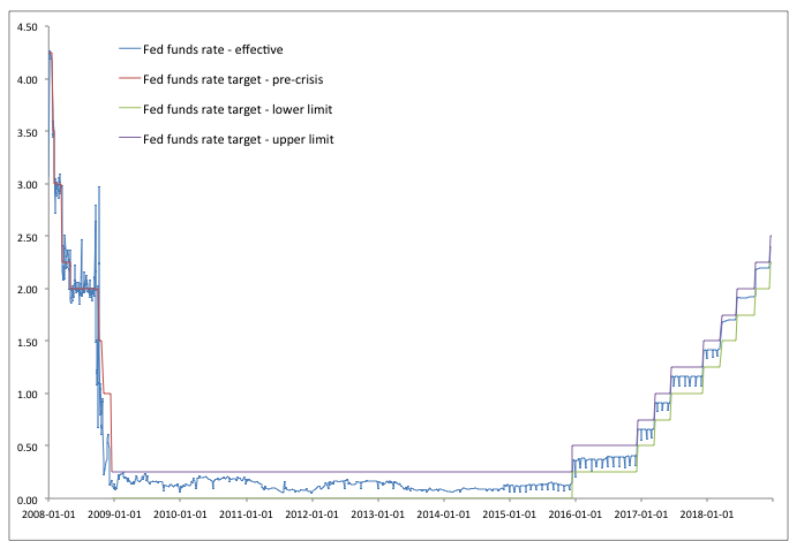

Figure 7. Federal funds rate and target range December 2008 - December 2018 (Interest rates, annual percent) Sources: Federal Reserve Bank of St. Louis and the author.

In the run-up to the lift-off, the FOMC modified its forward guidance in March 2015 to reflect progress that had been made in economic recovery and that an increase in the federal funds rate target was nearing. More specifically, it dropped reference to "can afford to be patient" from the FOMC press statement and stated that an increase in the target range for the federal funds rate will become appropriate when the FOMC sees further improvement in the labor market and is reasonably confident that inflation will return to its 2 percent objective over the medium term. Subsequently, it raised the target range for the federal funds rate, the first time since the onset of the financial crisis, by 25 basis points in December 2015, from zero to 25 basis points (Figure 7). To indicate that the right time was approaching for an increase in the interest rate, the FOMC indicated in its press statement in October 2015 that it might begin the lift-off in December, while emphasizing that no decision had yet been made. In its December meeting, members of the FOMC thought that conditions for the lift-off had been satisfied, as reflected in improvements in labor market conditions while the FOMC expressed confidence for inflation to return to the Federal Reserve's 2 percent objective over the medium term.

To reduce uncertainty about future monetary policy among the public, particularly among the financial markets, the policymakers clarified their longer-term intentions. The Federal Reserve issued in September 2014 a statement explaining the principles and plans for the policy normalization (Board of Governors of the Federal Reserve System, 2014b), which provided an update to the discussions that had taken place on this subject in June 2011 (Board of Governors of the Federal Reserve System, Minutes of the FOMC, 2011b). The September 2014 statement explained in detail the principles that would govern the timing and expected pace of policy normalization. These principles comprised modifications in the security holdings on the System Open Market Account (SOMA) of the Federal Reserve, changes in the forward guidance for the path of the federal funds rate, and adjustments in the federal funds rate target and the interest rate to be paid on banks' excess reserves with the Federal Reserve System. A further augmentation to the policy normalization principles and plans was issued in March 2015, and again in June 2017. As the recovery progressed, it permitted the Federal Reserve to outline in detail its normalization strategy. For instance, the Federal Reserve noted in March 2015 that it would continue to maintain the width of the target range for the federal funds rate at 25 basis points while it clarified further the roles of the upper and lower bounds of the target range and the use of the overnight reverse repurchase operations to support its monetary policy implementation. In June 2017, the Federal Reserve announced specific targets to be used during the process of reducing the holdings of its Treasury securities (Board of Governors of the Federal Reserve System, 2015b and 2017a). These not only improved transparency, but helped limit unintended consequences of the FOMC's policy decisions.

Clear communication was aimed at minimizing adverse reactions to policy changes, particularly related to rate increases in the near future. Consequently, the FOMC stated that monetary policy stance remained accommodative following the lift-off. Because of uncertainties, particularly related to the future path of inflation, the FOMC stressed that economic conditions would warrant only gradual increases in the federal funds rate, which was likely to remain, for some time, below the longer run level of federal funds rate (referring to the estimates of 'neutral' interest rate, which many thought was close to zero or even negative at the time and was expected to rise only slowly as the headwinds receded). The actual path was contingent on the economic outlook as informed by the incoming data (i.e., rate was not set on a pre-determined path). At the time the Federal Reserve's ability to offset the effects of 
unanticipated economic shocks was asymmetric. Therefore the FOMC took a cautious approach to normalization in order to minimize the risk of having to respond to a negative economic shock while the policy rate remained near its effective lower bound (see Board of Governors of the Federal Reserve System, FOMC press statement, 2015c).

Reflecting uncertainties surrounding the economy and the outlook, the Federal Reserve has demonstrated flexibility in the normalization of its monetary policy stance. In the subsequent 3 years following the lift-off, consistent with its commitment to a gradual approach, the Federal Reserve has increased the federal funds rate target range only eight times, to the range from 225 to 250 basis points (as of December 2018). Each increase in the federal funds rate target has been 25 basis points. However, their pacing has been highly uneven, as the federal funds rate target was increased only once in 2016 following the lift-off. Since December 2017, the Federal Reserve has followed quarterly increases in the target range for the federal funds rate. During the normalization process inflation (or lack of it) has been a dominant concern among the FOMC members, whereas output growth and employment have performed strongly. That is, members of the FOMC have struggled to gain a clear handle, on the one hand, what was behind the lackluster growth of labor compensations, while the labor market has remained increasingly tight, and on the other hand, of the benign performance of consumer prices at the time when economic activity remained strong (Kovanen, $2017 \mathrm{~b}$, offers a discussion on possible factors to help explain the wage growth puzzle).

The FOMC modified its forward guidance again, as the policy objectives of maximum employment and inflation were increasingly achieved. For instance, as inflation picture strengthened, the FOMC added the wording "symmetric" in its press statement in March 2017 to communicate that the 2 percent inflation objective was not an effective ceiling, but inflation could run above the policy objective for sometime without automatically triggering a policy action. Minutes of the March 2017 FOMC meeting further clarified the policymakers' thinking on a symmetric inflation objective, implying that the FOMC would adjust the monetary policy stance in response to inflation that was either above or below the 2 percent inflation objective on a sustained basis (Note 15).

However, concerns about the near-term path of inflation lingered. While the target range for the federal funds rate was increased in December 2017, differences regarding views about future increases in the federal funds rate target continued. Participants noted that survey-based inflation expectations and market based inflation compensations had remained weak, and other persistent factors might be holding down inflation, which could present a challenge for the FOMC in promoting return to the 2 percent inflation objective over the medium term. They thought that leaving the rate target unchanged, until actual inflation had moved further toward the Committee's 2 percent longer-term objective or inflation expectations had increased, would support the achievement of the policymakers' inflation objective.

A more consistent view of the economic outlook emerged in June 2018. As concerns about low inflation dissipated, a substantial revision in the FOMC press statement was introduced. The participants judged that with the economy strong and inflation expected to remain near the Committee's symmetric 2 percent objective over the medium term, the specific reference in the FOMC press statement that the federal funds rate is likely to "remain, for some time, below levels that are expected to prevail in the longer run", was considered no longer appropriate (Board of Governors of the Federal Reserve System, FOMC press statement, 2018f).

Minutes of the FOMC meeting in September 2018 highlighted a strong economy, with the labor market continuing to strengthen and output rising strongly. At the same time, inflation as measured by the PCE price index remained near the 2 percent objective and longer-term inflation expectations were unchanged (however, Clarida (2018b) has raised concerns that inflation readings remain relatively benign). Economic forecasts prepared by staff showed that output is projected to rise at a rate at or above economy's potential during 2018 through 2020, and then slowing to below potential in 2021. Unemployment rate is projected to remain below the long-run natural rate and bottom out in 2020, before edging up in 2021. Staff projections of the PCE inflation remain near the FOMC's 2 percent objective over the medium term, whereas the core PCE was projected to run somewhat below the overall rate of inflation over this period due to expected decline in energy prices.

To reflect the substantial progress achieved in the policy normalization, a further modification in the FOMC press statement was introduced in September 2018. The participants generally agreed that the economy was evolving as anticipated, and that it would be appropriate for the FOMC to remove wording "the stance of monetary policy remains accommodative" from the press statement. They thought that this characterization was no longer providing meaningful information about the uncertainties surrounding the level of neutral interest rate and it was appropriate to remove the wording before the target range for the federal funds rate moved closer to the range of estimates of the neutral policy rate. The FOMC underscored that the change should not be interpreted as a policy signal. In addition, as the FOMC stated that for some time adjustments in the path for the policy rate have depended on the evolution of 
economic outlook and risks to the outlook. The estimated level of the neutral rate is only one of the factors considered by the FOMC when making policy decisions. Furthermore, some participants thought that it would be necessary to increase the federal funds rate temporarily above the longer-run (neutral) level. However, some participants did not share this view and argued against a more restrictive monetary policy stance unless there were clear signs that the economy was overheating or inflation pressures were increasing.

The press statement following the November 2018 FOMC meeting was little changed from its September counterpart (Note 16). It signaled that in the absence of an unexpected slowdown in the economy, another 25 basis points increase would most likely occur in the December 2018 meeting (Board of Governors of the Federal Reserve System, Minutes of the FOMC, 2018d). Few participants were concerned about the timing of such increase whereas a couple noted that the federal funds rate might already be near its neutral level. In the November 2018 meeting, participants indicated that it might be appropriate to begin transition in the language of the press statement towards placing more emphasis on incoming data in the assessment of policy outlook. Consistent with this position, the participants anticipated that reference to "further gradual increases" in the target range for the federal funds rate may need to be removed from the press statement in the coming meetings, indicating that monetary policy normalization nears completion. In its December 2018 meeting, the FOMC increased the target range for the federal funds rate another 25 basis points, as was widely expected. Furthermore, it modified the language of the press statement, to emphasize the role of judgment in future interest rate decisions and the role of economic and financial developments in assessing its macroeconomic outlook (see Board of Governors of the Federal Reserve System FOMC press statement, 2018g).

\section{Perspectives From Past Interest Rate Cycles}

Despite differences in underlying economic trends, past tightening cycles offer valuable lessons to understand the Federal Reserve's monetary analysis and its communication practices. Although it is apparent that the FOMC's forward guidance has evolved and has become more focused during the post-financial crisis period, in many ways the policymakers' forward guidance during the 2004-2006 tightening cycle could be viewed as a pre-cursor for the post-financial crisis policy communication pattern. That is, some of the elements in forward guidance were present in the press statements during earlier periods and provided information about major shifts in U.S. monetary policy. In this section, we examine earlier tightening cycles and highlight changes in macroeconomic developments that have intertwined with the Federal Reserve's monetary policy decisions and communication practices.

\subsection{Interest Rate Trends During Tightening Cycles}

There have been four tightening cycles since the early 1990s, during which the federal funds rate has been brought to a 'normal' level (Figure 8). Three of them were associated with economic recoveries, following a period during which policy interest rates were lowered substantially. The fourth tightening cycles, on the other hand, could be considered as a late-business cycle hike in interest rates, which responded to specific economic conditions (Note 17).

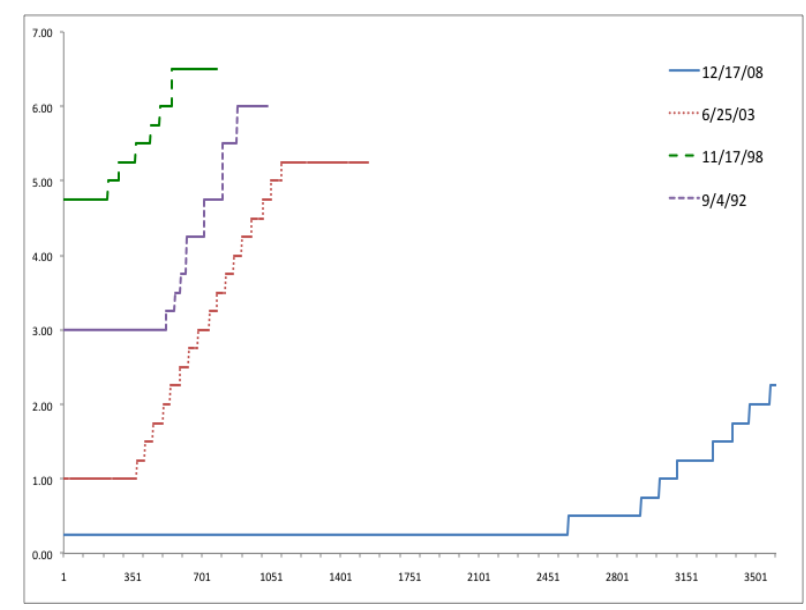

Figure 8. Policy interest rate paths for selected tightening cycles; rebased (number of days) (In annual percent)

Sources: Federal Reserve Bank of St. Louis and the author.

In attempting to compare interest rate policies across different interest rate cycles, we recognize that each of them is 
unique and influenced by specific circumstance. We are aware of the changes in the Federal Reserve's operating framework over the past three decades, particularly after the financial crisis when the Federal Reserve adopted a totally different operating framework that comprised a range for the federal funds rate (see Lindsey (2003) for a useful discussion on the policy frameworks for earlier periods). It is therefore possible that changes in the operating frameworks that have taken place during the past decades have influenced the role of the policy interest rate in the implementation of monetary policy (for instance, the shift from managing banks' reserve positions to the federal funds rate target was only introduced in August 1997; see Board of Governors of the Federal Reserve System, Minutes of the FOMC, 1997).

Nevertheless, the path of the post-financial crisis interest rate cycle stands out. First, the beginning of the tightening cycle (or the lift-off) was preceded by an extraordinarily long period of near zero interest rates (from December 2008 until the lift-off in December 2015), which was longer than during any earlier tightening cycle at least since the 1990s. It reflected the depth of the recession and the painfully slow and uncertain recovery that followed, warranting extreme caution from the Federal Reserve. Furthermore, the process of normalization following the lift-off has been unique relative to the previous tightening cycles. The pace of increasing the policy interest rate has been much slower than in the past. The FOMC has increased the target range for the federal funds rate 9 times between December 2015 and December 2018, each comprising a 25 basis points increase in the policy rate. Only since December 2017 interest rate hikes have followed a regular, quarterly, schedule.

During previous tightening cycles, the federal funds rate target was raised much more aggressively. This is true in terms of the time it took to reach a 'normal' level of the policy interest rate and in terms of the size of the overall increase. The tightening cycle that started in June 2004, in the aftermath of the 2001 downturn, lasted two years but comprised 17 increases in the federal funds rate target totaling 425 basis points, from 100 basis points to 525 basis points (reached in June 2006). The pace of increases in the federal funds rate target that followed the 1990 recession was also steep, as the policy rate was increased by 300 basis points during a period of a year. The tightening cycle that begun in June 1999 may be considered an outlier because it was not related to a recession, but instead represented a response by the policymakers to a late-business cycle increase in inflation pressures. This tightening cycle comprised 6 increases in the interest rate, totaling 175 basis points, over a period of 11 months.

\subsection{Highlights From Earlier Tightening Episodes}

\subsubsection{Monetary Analysis}

The decision to halt raising interest rates is often associated with a substantial degree of uncertainty. Our earlier discussion vividly illustrates that there is no risk-free path to monetary policy formulation. The signs of slowing economic activity are often inconsistent. Balancing various risks and uncertainties therefore plays critical importance in policy formulation. For instance, when the Federal Reserve decided to pause in March 1995, the signs of slower economic growth were limited and it was not evident to the policymakers how slowing economic growth would impact cost pressures in the labor and other resource markets. The policymakers remained uncertain if inflation would moderate in the absence of further monetary restraint, as indicated in the minutes of the March 1995 FOMC meeting (Board of Governors of the Federal Reserve System, Minutes of the FOMC, 1995a) (Note 18). Ending the tightening cycle in March 1995 represented a significant change in the policymakers' assessment and illustrated the unpredictable nature of economic dynamics. In early 1995, data suggested that economic growth had accelerated during the closing months of the previous year (Note 19). Although consumer spending was less buoyant and the housing market had softened somewhat, business fixed investments, exports and inventories continued to grow briskly, and gains in industrial output and employment continued (Note 20). Members of the FOMC were concerned about uncertainties surrounding external sector outlook, while the defeat of balanced budget amendment in Congress had clouded the outlook for government fiscal deficit. Concerns remained that cost pressures might lead to higher inflation in the future.

During the late-business cycle tightening in 2000 , the policymakers responded to a moderation in economic activity. The decision to discontinue raising interest rates in June 2000 also reflected the relatively forceful tightening in May 2000 when the federal funds rate was increased by 50 basis points (in earlier periods the federal funds rate target was raised by 25 basis point in each meeting). Slower consumer spending, which rose only modestly, together with moderating housing market data, provided evidence of softening demand. Industrial production and demand for labor were still expanding, but at reduced rates. Sizeable increases in energy prices had boosted headline inflation somewhat and some members of the FOMC were concerned that the unsustainably tight labor market could put upward pressure on core inflation, which for the time being remained contained as the result of productivity growth. However, uncertainties surrounding the economic outlook and in particular the extent and duration of the earlier 
moderation in spending, together with the effects of previous tightening, reinforced the argument for leaving the stance of policy unchanged at the June 2000 meeting while allowing the policymakers' to assess incoming data carefully (the FOMC kept the policy interest rate at 5.25 percent until September 2007 when it was lowered to 4.75 percent, and subsequently to near zero as the financial crisis advanced).

Similarly, concerns about inflation featured in the FOMC's decision to pause in August 2006 as signs of slowdown emerged. Staff forecasted that output would slow below a rate that had been anticipated in the previous forecast. Demand for labor had also eased, as nonfarm payroll increased at a reduced rate than in the first quarter. But consumer price inflation remained elevated as headline inflation continued to increase due to rising energy prices and rising cost of shelter, although long-term inflation expectations remained contained. Core consumer price inflation was running at or above 2 percent annual rate but was projected to recede somewhat later in the year. With a slowdown in the housing market, staff expected that higher energy prices and the effects of past policy tightening would contain growth below potential over the coming six quarters, despite further gains in industrial production and manufacturing. The policymakers were concerned that elevated resource utilization and high prices of energy and other commodities could result in sustained inflationary pressures, even if moderation in aggregate demand growth would limit inflation pressures over time.

Pass-through from earlier policy tightening also played a role in the policy decisions. Factoring this into the policy assessment is often complicated because monetary policy influences the economy with relatively long and variable lags (which may not be fully quantifiable). For instance, the decision to pause in March 1995 allowed the Committee to assess the underlying strength of the economy and the impact of previous interest rate increases on the economy more thoroughly while not committing to a particular direction for future interest rate. As further evidence of economic slowdown emerged in the subsequent period, this allowed the FOMC to maintain the federal funds rate target unchanged at 6.0 percent during subsequent meetings (the policy rate target was lowered by 25 basis points in July 1995). Similarly, keeping the monetary policy stance unchanged in August 2006 gave the Committee time to accumulate information before deciding whether additional firming was needed to attain price stability over time.

\subsubsection{Communication}

The FOMC's communication on monetary policy evolved significantly during these episodes. The FOMC started to publish in February 1994 its policy decision immediately after each meeting although the press statements at the time did not explicitly refer to the numerical target for the federal funds rate (see Lindsey, 2003). The press announcements evolved during the following year and indicated more clearly that an increase in the policy rate target would be "reflected fully" in the reserve market (see, for instance, Board of Governors of the Federal Reserve System, FOMC press statement, 1995b). Although the length of press statements grew and the Federal Reserve incorporated additional details about current monetary policy and the possible timing of future policy actions into the statements, active forward guidance was not apparent at the time. For instance, forward guidance during 1994-1995 remained unchanged despite changes in the FOMC's policy assessment (rules for announcing policy decisions were formalized in February 1995).

There were important modifications in the FOMC press statements in the run-up to pausing in May 2000. Until December 1999, the press statements underscored symmetry in the policy adjustment going forward, but after the February 2000 FOMC meeting, the press statement was shortened considerably, leaving out many background developments and focusing on monetary policy (Board of Governors of the Federal Reserve System, FOMC press statement, 2000a). Furthermore, the press statement highlighted inflationary risks going forward. However, even after the FOMC paused its campaign to raise the federal funds rate, the statement was left unchanged reflecting remaining inflation risks. As the balance of risks shifted towards economic weakness, the FOMC modified the press statement in December 2000 and pointed out that risks were weighted more toward conditions associated with economic weakness in the foreseeable future (Board of Governors of the Federal Reserve System, FOMC press statement, 2000b). Subsequently, the FOMC lowered the policy rate target by 50 basis points in January 2001 .

Prior to pausing in August 2006, the FOMC tailored its forward guidance more toward particular economic conditions. During the subsequent period, the forward guidance was actively modified as the economic conditions changed. This illustrates features of policy communication present in the post-financial crisis guidance. As the economy recovered and deflation risks started to abate, the FOMC included in January 2004 in its press statement the wording: "it can be patient in removing its policy accommodation". The statement explained that the probability of unwelcome fall in inflation has diminished in recent months and appears almost equal to that of a rise in inflation. With inflation low and slack in resource utilization, the Committee thought that it could be patient in removing policy accommodation. As conditions improved during 2004, the FOMC statement was modified again. The 
Committee perceives that the risks to price stability had moved into balance. With inflation still low and resource availability adequate, the Committee saw that policy accommodation could be removed at a pace that was likely to be "measured". In June 2004, with further progress achieved in economic recovery, albeit inflation low, the Committee wanted to underscore the risks to price stability and included wording to note that it will respond to the changes in economic prospects as needed to fulfill its obligation to maintain price stability. In March 2005, as inflation pressures fell, the word "contained" in the press statement was replaced by "low".

Forward guidance was modified again in December 2005 to address the prospect for further policy firming. The press statement pointed to further policy firming that may be needed to keep the risks to the attainment of both sustainable economic growth and price stability roughly in balance. In addition, the Committee noted that it would respond to changes in economic prospects as needed to foster these objectives. In May 2006, the FOMC increased its emphasis on inflation in the press statement, by stating that "some further policy firming may yet be needed to address inflation risks", but underscored that the extent and timing of such firming would depend on the evolution of the economic outlook as implied by incoming information.

As inflation pressures were expected to ease, the FOMC modified its guidance in June 2006. This shift in the policy assessment was clarified in the press statement, by maintaining emphasis on lingering inflation risk. In August 2006, the FOMC simplified its press statement but continued to emphasize that the extent and timing of additional policy firming would depend on the evolution of outlook for inflation and economic growth, as implied by incoming data. As economic conditions evolved, the word 'nonetheless' was added to the press statement in the September 2006 FOMC meeting, to reflect remaining inflation risk.

\section{Conclusion and Final Thoughts}

In this paper, we draw parallels to earlier interest rate cycles to gain perspectives to the Federal Reserve's monetary policy decision-making and communication during the post-financial crisis period. Although the current interest rate cycle has many unique features, it also shares similarities with past tightening episodes. We draw on these commonalities to shed light on the policymakers' analysis and how they are reflected in the FOMC's policy decisions, in particular at the time when the FOMC is close to ending its campaign of raising interest rates. Given the importance of judgment and subtleties in policy communication at the time when monetary policy is close to a 'normal' level, perspectives from the past are expected to assist in understanding the current normalization process and factors that might inform us about the future policy decisions.

Forward guidance has become an integral part of the Federal Reserve's communication. While the Federal Reserve has shown remarkable ability to modify its forward guidance in response to changing economic circumstance during the recovery from the financial crisis, it already took steps towards more active use of forward guidance in its policy communication during the 2004-2006 recovery period. Some of the main elements in guiding public expectations during the policy normalization in that period were present in the Federal Reserve's communication, which help us better understand how the FOMC might modify forward guidance in the coming period, as the policymakers reach the end of the normalization process.

Monetary policy is invariably implemented in an environment of incomplete information. It implies that the policymakers have to deal with various sources of uncertainties, which have the potential to significantly influence future developments and the accuracy of their projections. We have noted that although each business cycle has its unique features, economic developments are never totally random and therefore there are certain regularities in behavioral relations that might be followed with some degree of confidence. Placing current developments, such as the unemployment rate, currency appreciation, and the yield curve, into a longer-term context helps in understanding these issues and their implication for policy formulation.

Significant uncertainties arise from the estimates of the neutral rates of interest and unemployment. As we have discussed, these variables (i.e., $i^{*}$ and $u^{*}$ ) are not only frequently cited in the FOMC policy discussions, but they play critical roles in the policy assessment. It is therefore important to ensure that the policymakers' estimates are accurate, given their implications for policy decisions.

Balancing upside and downside risks is going to be important for policy decisions. At the moment, the U.S. economy is in a 'goldilocks' position where there are no significant imbalances either way. Although the economy is performing strongly and labor markets remain tight, the potential for rising inflation is probably the most important upside risk, which is yet to materialize. The PCE price index has only increased by 1.8 percent in the year to November 2018 while inflation expectations appear to be at the lower end of the range consistent with price stability. Furthermore, the Federal Reserve's projections of inflation pressures in the twelve-month period ahead point to 
inflation remaining comfortably in the 1.5 and 2.5 percent range (the probability was around 70 percent in November 2018). These should provide the Federal Reserve some space to err on the cautious side. Nevertheless, the policymakers need to act prudently and continue to emphasize inflation risks in their future communication.

On the downside, risks associated with the global economy have probably increased. These reflect, among other, ongoing trade tensions and economic slowdown in Europe and in parts of Asia. Furthermore, in the U.S. economic and trade policy uncertainties have increased, while market volatility has intensified. These should warrant caution in the coming period even if their impact may be difficult to quantify. Given the low risk of higher inflation in the period ahead, this may provide a good moment to take stock of the impact of earlier interest rate decisions on the economy before moving forward. The policymakers have already taken a substantial effort in raising interest rates (i.e., during the past 3 years the Federal Reserve has increased the target range for the federal funds rate by a total of 250 basis points) and there are uncertainties involved in the transmission of monetary policy to the economy.

Past communication practices could inform us about the Federal Reserve's future policy direction. Based on this, we argue that the modifications in the Federal Reserve's press statement following the December 18-19, 2018 FOMC meeting could signal an end to the policy normalization. Although the FOMC retained reference to "further gradual increases" in the December 2018 press statement, at the same time it is increasingly emphasizing the importance of economic data in assessing risks to the economic outlook. In many ways, this is similar to changes that were adopted by the FOMC in August 2006 when the Federal Reserve paused. At the time, the FOMC also modified the press statement to underscore that the extent and timing of any additional firming that may be needed would depend on the evolution of the outlook for both inflation and economic growth, as implied by incoming information. Furthermore, the policymakers seem to have indicated in December 2018 that the path of future rate increases may no longer be unidirectional, by placing increasing emphasis on judgment in policy decisions. This would be consistent with the intent to move to a 'normal' monetary policy stance and signals that the future direction of interest rates may be either up or down, depending on incoming data. But in the end of the day, only time will tell, since the policymakers' are not committed to a particular path for the federal funds rate, as future policy decisions will continue to depend primarily on incoming data.

\section{Acknowledgement}

The author likes to express his gratitude to the editor and reviewers for their comments and suggestions. All remaining errors are the responsibility of the author.

\section{References}

Bansak, C., Morin, N., \& Starr, M. (2004, May). Technology, Capital Spending, and Capacity Utilization. Federal Reserve Board, Washington, D.C.

Barsky, R., Justiniano, A., \& Melosi, L. (2014, May). The Natural Rate and its Usefulness for Monetary Policy Making. American Economic Review, Papers and Proceedings, 104, 37-43. https://doi.org/10.1257/aer.104.5.37

Bauer, M. D., \& Mertens, T. M. (2018, August 27). Information in the Yield Curve about Future Recessions. Economic Letter, 20, 1-5. Federal Reserve Bank of San Francisco.

Bean, C. (2006, October). Globalization and Inflation. Speech at the LSE Economic Society, London School of Economics. Retrieved from www.bankofengland.co.uk

Bernanke, B. S. (2012, August 31). Monetary Policy since the Onset of the Crisis. Remarks at the Federal Reserve Bank of Kansas City Economic Symposium, Jackson Hole. Wyoming.

Bernanke, B. S. (2013, November 19). Communication and Monetary Policy. Remarks at the National Economists Club Annual Dinner, Herbert Stein Memorial Lecture. Washington, D.C.

Bernanke, B. S. (2017a, October 2). Monetary Policy in a New Era. Brookings Institution. Washington, D.C.

Bernanke, B. S. (2017b, January 27). Shrinking the Fed's Balance Sheet. Brookings Institution. Washington, D.C.

Blecker, R. (2007, February). The Economic Consequences of Dollar Appreciation for U.S. Manufacturing Investment: A Time-Series Analysis. International Review of Applied Economics, 21(4), 491-517. https://doi.org/10.1080/02692170701474595

Board of Governors of the Federal Reserve System. (1995a, March 28). Minutes of the FOMC.

Board of Governors of the Federal Reserve System. (1995b, February 1). FOMC Statement. Press Release.

Board of Governors of the Federal Reserve System. (1997, August 19). Minutes of the FOMC. 
Board of Governors of the Federal Reserve System. (2000a, February 2). FOMC Statement. Press Release.

Board of Governors of the Federal Reserve System. (2000b, December 19). FOMC Statement. Press Release.

Board of Governors of the Federal Reserve System. (2000c, February 1-2). Minutes of the FOMC.

Board of Governors of the Federal Reserve System. (2008, December 16). FOMC Statement. Press Release.

Board of Governors of the Federal Reserve System. (2009, March 18). FOMC Statement. Press Release.

Board of Governors of the Federal Reserve System. (2011a, August 8). FOMC Statement. Press Release.

Board of Governors of the Federal Reserve System. (2011b, June 21-22). Minutes of the FOMC.

Board of Governors of the Federal Reserve System. (2014a, March 30). FOMC Statement. Press Release.

Board of Governors of the Federal Reserve System. (2014b, September 17). Federal Reserve Issues FOMC Statement on Policy Normalization Principles and Plans. Press Release.

Board of Governors of the Federal Reserve System. (2015a, October 27-28). Minutes of the FOMC.

Board of Governors of the Federal Reserve System. (2015b, March 18) FOMC Issues Addendum to the Policy Normalization Principles and Plans. Press Release.

Board of Governors of the Federal Reserve System. (2015c, March 18). FOMC Statement. Press Release.

Board of Governors of the Federal Reserve System. (2017, June 14). FOMC Issues Addendum to the Policy Normalization Principles and Plans. Press Release.

Board of Governors of the Federal Reserve System. (2018a, November 15). Federal Reserve to Review Strategies, Tools, and Communication Practices It Uses to Pursue Its Mandate of Maximum Employment and Price Stability. Press Release.

Board of Governors of the Federal Reserve System. (2018b, November 8). FOMC Statement. Press Release.

Board of Governors of the Federal Reserve System. (2018c, September 25-26). Minutes of the FOMC.

Board of Governors of the Federal Reserve System. (2018d, November 7-8). Minutes of the FOMC.

Board of Governors of the Federal Reserve System. (2018e, January 30). Statement on Longer-Run Goals and Monetary Policy Strategy.

Board of Governors of the Federal Reserve System. (2018f, June 13). FOMC Statement. Press Release.

Board of Governors of the Federal Reserve System. (2018g, December 18-19). FOMC Statement. Press Release.

Bonis, B., Ihrig, J., \& Wei, M. (2017, April 20). The Effect of the Federal Reserve's Securities Holdings on Longer-term Interest Rates. FEDS Notes, Board of Governors of the Federal Reserve System.

Calstrom, C. T., \& Fuerst, T. S. (2016, March 22). The Natural Rate of Interest in Taylor Rules. Economic Commentary, 2016-01, Federal Reserve Bank of Cleveland.

Campbell, J. R. (2013). Odyssean Forward Guidance in Monetary Policy: A Primer. Economic Perspectives, pp. 130-39. Federal Reserve Bank of Chicago.

Carner, A. C. (1994). Capacity Utilization and U.S. Inflation. Economic Review, 4(4), 5-21. Federal Reserve Bank of Kansas City.

Cette, G., Fernald, J. G., \& Mojon, B. (2016). The Pre-Great Recession Slowdown in Productivity. Working Paper 2016-08, Federal Reserve Bank of San Francisco, Working Paper Series.

Christensen, J. H. E. (2018, October 15). The Slope of the Yield Curve and the Near-Term Outlook. Economic Letter, 23, 1-5. Federal Reserve Bank of San Francisco.

Clarida, R. H. (2018a, October 25). Outlook for the U.S. Economy and Monetary Policy. Speech at Peterson Institute for International Economics, Washington, D.C.

Clarida, R. H. (2018b, November 27). Data Dependence and U.S. Monetary Policy. Remarks at the Clearing House and the Bank Policy Institute Annual Conference, New York, New York.

Daly, M. C., \& Hobijn, B. (2016). The Intensive and Extensive Margins of Real Wage Adjustment. Working Paper Series, 2016-04, Federal Reserve Bank of San Francisco. https://doi.org/10.24148/wp2016-04

Díez, F. J., \& Gopinath, G. (2015). The Effects of a Stronger Dollar on U.S. Prices. Current Policy Perspectives, No. 
15-9, Federal Reserve Bank of Boston.

Dorich, J., Reza, A., \& Sarker, S. (2017). An Update on the Neutral Rate of Interest. Bank of Canada Review, Autumn, 27-41.

Estrella, A., \& Mishkin, F. S. (1996, June). The Yield Curve as a Predictor of U.S. Recession. Current Issues in Economics and Finance, 2(7), 1-6. Federal Reserve Bank of New York.

Estrella, A., \& Trubin, M. R. (2006, July/August). The Yield Curve as a Leading Indicator: Some Practical Issues. Current Issues in Economics and Finance, 12(5), 1-7. Federal Reserve Bank of New York. https://doi.org/10.2139/ssrn.1001228

Fabià, G.-B., \& Olivei, G. P. (2013, April). An Evaluation of the Federal Reserve Estimates of the Natural Rate of Unemployment in Real Time. Federal Reserve Bank of Boston.

Federal Reserve Bank of St. Louis, FRED. (n.d.) Reteieved from https://fred.stlouisfed.org

Greenspan, A. (1996, December 5). The Challenge of Central Banking in a Democratic Society. Remarks at the Annual Dinner and Francis Boyer Lecture of the American Enterprise Institute for Public Policy Research. Washington, D.C.

Greenspan, A. (1997, January 21). Performance of the U.S. Economy. Testimony before the Committee on the Budget, United States Senate.

Holston, K., Laubach, T., \& Williams, J. C. (2016, June). Measuring the Natural Rate of Interest: International Trends and Determinants. Working Paper Series 2016-11, Federal Reserve Bank of San Francisco.

International Monetary Fund. (2006, April). How Has Globalization Changed Inflation?. World Economic Outlook, pp. 97-134. International Monetary Fund.

International Monetary Fund. (2018). Annual Report on Exchange Rate Arrangements and Exchange Restrictions, 2017. International Monetary Fund.

Koenig, E. F., \& Armen, A. (2017, February). Navigating by the Stars: The Natural Rate as Economic Forecasting Tool. Economic Letter, 12(2), 1-4. Federal Reserve Bank of Dallas.

Kovanen, A. (2014). When Should the Fed Begin Monetary Policy Tightening?. Unpublished. Retrieved from https://independent.academia.edu/ArtoKovanen

Kovanen, A. (2017a). Wage Growth Puzzle and Capacity Utilization. Unpublished. Retrieved from https://independent.academia.edu/ArtoKovanen

Kovanen, A. (2017b). A Note of Caution About the Fed's Policy Tightening. Unpublished. Retrieved from https://independent.academia.edu/ArtoKovanen

Kovanen, A. (2017c). Should the Fed Worry About the Size of Its Balance Sheet?. Unpublished. Retrieved from https://independent.academia.edu/ArtoKovanen

Krustev, G. (2018, July). The Natural Rate of Interest and the Financial Cycle. Working Paper Series, No. 2168. European Central Bank.

Laubach, T., \& Williams, J. C. (2003, November). Measuring the Natural Rate of Interest. Review of Economics and Statistics, 85(4), 1063-70. https://doi.org/10.1162/003465303772815934

Lindsey, D. E. (2003). A Modern History of FOMC Communication: 1975-2002. Board of Governors of the Federal Reserve System, FOMC Secretariat.

Liu, Z. (2018, December 13). Fed Views. Economic Research Department, Federal Reserve Bank of San Francisco.

Lubic, T. A., \& Matthes, C. (2015, October). Calculating the Natural Rate of Interest: A Comparison of Two Alternative Approaches. Economic Brief, EB15-10, Federal Reserve Bank of Richmond.

National Bureau of Economic Research (NBER). U.S. Business Cycle Expansions and Contractions. Retrieved from www.nber.org/cycles/cyclesmain.html

Orphanides, A., \& Williams, J. C. (2002). Robust Monetary Policy Rules with Unknown Natural Rates. Brookings Papers on Economic Activity, 2, 63-145. https://doi.org/10.1353/eca.2003.0007

Powell, J. H. (2018a, October 2). Monetary Policy and Risk Management at a Time of Low Inflation and Low Unemployment. Remarks at the "Revolution or Evolution" Reexamining Economic Paradigms", 60th Annual 
Meeting of the National Association for Business Economics, Boston, Massachusetts. https://doi.org/10.1057/s11369-018-0099-8

Powell, J. H. (2018b, November 28). The Federal Reserve's Framework for Monitoring Financial Stability. Remarks at the Economic Club of New York, New York.

Reich, M. (2010, June). High Unemployment after the Great Recession: Why? What Can We Do?. Policy Brief, Center on Wage and Employment Dynamics, Institute for Research on Labor and Employment, University of California, Berkeley.

Reifschneider, D. (2016, August). Gauging the Ability of the FOMC to Respond to Future Recessions. Finance and Economics Discussion Series, 2016-068, Washington, Board of Governors of the Federal Reserve System.

Roberts, J. M. (2018, September 5). An Estimate of the Long-Term Neutral Rate of Interest. FEDS Notes, Board of Governors of the Federal Reserve System.

Shapiro, A. (2018, November 9). FedViews. Economic Research Department, Federal Reserve Bank of San Francisco.

Staiger, D., Stock, J. H., \& Watson, M. W. (2001, June). Prices, Wages and the U.S. NAIRU in the 1990s. Working Paper 8320, National Bureau of Economic Research.

Taylor, J. B. (1993). Discretion versus Policy Rules in Practice. Carnegie-Rochester Conference Series on Public Policy, 39, 195-214. https://doi.org/10.1016/0167-2231(93)90009-L

Williams, J. C. (2018, September 28). 'Normal' Monetary Policy in Words and Deeds. Speech given at Columbia University, School of International and Public Affairs, New York City, New York.

Yellen, J. L. (2013, April 4). Communication in Monetary Policy. Remarks at the Society of American Business Editors and Writers 50th Anniversary Conference, Washington, D.C.

Yellen, J. L. (2014, May 7). Statement by Chair of the Board of Governors of the Federal Reserve System before the Joint Economic Committee of the U.S. Congress.

Yellen, J. L. (2016, August 26). The Federal Reserve's Monetary Policy Toolkit: Past, Present, and Future. Remarks made at a symposium for "Designing Resilient Monetary Policy Framework for the Future", sponsored by the Federal Reserve Bank of Kansas City, Jackson Hole, Wyoming.

Yellen, J. L. (2017, September 26). Inflation, Uncertainty, and Monetary Policy. Remarks at the 59th Annual Meeting of the National Association for Business Economics on "Prospect for Growth: Reassessing the Fundamentals", Cleveland, Ohio.

\section{Notes}

Note 1 . The choice of the operating framework could have implications for the program aimed at reducing the size of the Federal Reserve's balance sheet.

Note 2. See the testimony of Chairman Alan Greenspan on the performance of U.S. economy before the Committee on the Budget, United States Senate (January 21, 1997).

Note 3.There are, of course, other risk factors that the policymakers account for when discussing monetary policy, as mentioned in the September 2018 FOMC minutes. We, however, abstract from these for the most part in the interest of conserving space.

Note 4. For each recovery cycle in Figures 1 through 5, lines have been drawn "from peak to peak" where peak is the end of an economic expansion and start of an economic contraction (denoted as $\mathrm{T}=0$; see additional details on business cycle turning points at https://www.nber.org/cycles/cyclesmain.html).

Note 5. Bansak et al. (2004) show that technology could lower the average cost of spare capacity, which enables firms to retain unused capacity to respond more quickly to temporary demand shocks.

Note 6. There were other factors that influenced inflation trends in the late 1990s, such as increasing labor productivity and strong U.S. dollar.

Note 7. Staiger et al. (2001) analyze the wage and price trends during the 1990s, and Gumbau-Brisa and Olivei (2013) evaluate the Federal Reserve's estimates of the NAIRU over a longer period of time.

Note 8. Nominal appreciation of the U.S. dollar during the current recovery has been modest by historical standards, 
amounting to about 25 percent, as oppose to 75 percent in the post-1990 recovery.

Note 9. The discussion on the future operating framework of the Federal Reserve in the November 2018 FOMC meeting suggest that the Federal Reserve's balance sheet may remain larger and not return to the level prior to the financial crisis. This could have implications for term premiums.

Note 10. Regarding the appropriate size of the Federal Reserve's balance sheet, Williams (2018) notes that this is still being analyzed and debated at the Federal Reserve, but it should be such that it would permit efficient and effective monetary policy implementation (e.g., see Bernanke, 2017b, and Kovanen, 2017c). Although balance sheet adjustment is an important feature of the post-financial crisis monetary policy normalization, and could also have implications for longer-term interest rates, we will abstract from this discussion for the most part in the paper.

Note 11. In his original presentation, Taylor (1993) used output gap $\left(y-y^{*}\right)$ instead of unemployment gap.

Note 12. In terms of the familiar Taylor rule (Equation 1), when inflation and unemployment rate are at their respective longer-term levels, inflation-adjusted policy interest rate would correspond to the natural rate $\left(r^{*}\right)$.

Note 13. Taylor rule (e.g., Equation 1) assumes that the federal funds rate consistent with full employment and price stability would be around 4 percent.

Note 14. Specific language was included in the FOMC press statements to guide the public about the likely changes in the policy rate target. In its December 2008 meeting, for instance, the FOMC included wording "for some time" to the press statement to describe the likely future path of monetary policy. It was changed to "for an extended period" in the March 2009 FOMC press statement.

Note 15. While keeping the federal funds rate target unchanged, the FOMC announced in the September 2017 meeting a plan to reduce the Federal Reserve's securities holding gradually to achieve a more normal size of its balance sheet.

Note 16. Shapiro (2018) sheds light into the inflation picture by noting that recent increases in inflation have been caused by industry-specific, secular, factors, which contribute half of a percentage point more to the overall core inflation than a year ago. Price increases for cyclically sensitive goods have remained fairly steady during the past year, despite improving economy. The median ten-year ahead PCE inflation forecast in the survey of professional forecasters has remained at 2 percent, with risks to the inflation outlook as balanced around the FOMC objective.

Note 17. For each rate tightening cycle the starting point in Figure 8 is the date when the Federal Reserve ended its monetary policy easing (i.e., when interest rates reached their lowest point during each cycle).

Note 18. While recession officially ended in March 1991, after which the U.S. economy started to gain speed, the FOMC continued to lower the policy interest rate significantly during the subsequent year and a half. The federal funds rate target stood at 8.0 percent when the recession started in July 1990 and only fell to 6.0 percent by the time the recession ended in March 1991.

Note 19. The robust incoming data underlined the policy action of the FOMC (federal funds rate target was raised by 50 basis points to 6.0 percent in the January-February 1995 meeting).

Note 20. In the January-February 1995 FOMC meeting, members also discussed aspects of inflation targeting. On the one hand, they thought that inflation targeting would help anchor monetary policy and could enhance credibility, and perhaps reduce the overall cost of attaining price stability. However, it was also thought that a close adherence to preset inflation targets could unduly constraint the Federal Reserve in its efforts to counteract the effects of cyclical shortfalls in economic performance. No firm decision was taken, except that members agreed that the subject would be revisited sometime in the future. An explicit inflation target was adopted in 2012, following the financial crisis. 